\title{
Restrukturyzacja i modernizacja hutnictwa żelaza Górnośląskiego Okręgu Przemyslowego po 1989 roku
}

Transformacja gospodarcza związana z przejściem od gospodarki centralnie planowanej do rynkowej, spowodowała zmiany w funkcjonowaniu przedsiębiorstw. Wcześniejszy cel ich działalności, jakim był wzrost produkcji, zmienił się w maksymalizację zysków. Dla polskiego hutnictwa oznaczało to konieczność zwiększenia efektywności pracy, zmniejszenia energochłonności i materiałochłonności technologii produkcyjnych oraz polepszenia jakości wytwarzanych wyrobów. Niezbędne były również zmiany asortymentu produkcji ze względu na zmniejszenie zapotrzebowania u dotychczasowych odbiorców, głównie w przemyśle wydobywczym, zbrojeniowym, maszynowym oraz w wyniku braku inwestycji modernizacyjnych infrastruktury kolejowej. Nałożył się na to problem zaostrzenia norm dotyczących ochrony środowiska, co wymuszało poniesienie nakładów na ograniczenie uciążliwości przedsiębiorstw w zakresie emisji pyłów i gazów, zrzutu ścieków oraz składowania odpadów.

Problematyka zawarta w temacie pracy była w różnych aspektach poruszana wielokrotnie (m.in. na łamach prasy gospodarczej). Jednocześnie brak w chwili obecnej opracowania ujmującego całościowo problematykę restrukturyzacji hutnictwa na obszarze GOP, uzasadnia podjęcie tematyki przez autora niniejszej pracy.

Celem pracy jest poznanie prawidłowości procesu restrukturyzacji i modernizacji hutnictwa żelaza Górnośląskiego Okręgu Przemysłowego oraz określenie możliwości jego dalszego funkcjonowania. $\mathrm{Z}$ tego punktu widzenia najbardziej interesujące jest rozważenie następujących zagadnien:

- różnice w sektorze hutnictwa żelaza krajów socjalistycznych i kapitalistycznych,

- zmiany w podaży i popycie wyrobów stalowych po wprowadzeniu mechanizmów gospodarki wolnorynkowej,

- czas rozpoczęcia przemian oraz finansowanie przekształceń branży hutniczej,

- dokonane przemiany w strukturze produkcji i modernizacji linii technologicznych,

- zmiany w zakresie uciążliwości hutnictwa w środowisku naturalnym,

- dotychczasowy stan dostosowania do wymogów rynku i perspektywa rozwoju hut.

Dla potrzeb opracowania, za obszar GOP-u przyjęto gminy położone w obszarze zwartej aglomeracji katowickiej na terenach występowania złóż węgla kamiennego. Jest to miejsce, w którym hutnictwo na skalę przemysłową rozwija się od około 200 lat. W 1989 roku funkcjonowało tu pod nazwą huta żelaza 16 przedsiębiorstw. W opracowaniu uwzględniono następujące huty: Baildon, Bankowa, Batory, Bobrek (obecnie Duostal), Buczek, Cedler, Ferrum, 1 Maja (Gliwice), Jedność, Katowice, Kościuszko, Łabędy, Łaziska i Pokój. Huty Zabrze i Zyg- 
munt ze względu na profil produkcji - maszyny i urządzenia, nie zostały uwzględnione $w$ analizie. Przy doborze przedsiębiorstw oparto się bowiem na klasyfikacji produkcji według EKD'. Nie wzięto też pod uwagę furm małych, jak ciagarnie drutu, kuźnie itp. Ich specyfika produkcji i przekształceń jest inna od analizowanych hut.

\section{Czynniki warunkujące zmiany w hutnictwie w wyniku transformacji gospodarczej}

W gospodarce krajów socjalistycznych przynależność i pełna kontrola przedsiębiorstw przemysłowych przez państwo decydowała o strukturze branżowej przemyslu, w której tzw. przemysł ciężki, w tym także hutnictwo, miał znaczenie priorytetowe. Wiązało się to w wysokimi nakładami inwestycyjnymi umożliwiającymi ich duży rozwój. Powodowało to efekt dodatniego sprzężenia zwrotnego, pomiędzy górnictwem, hutnictwem i energetyką, które to znaczną ilość towarów przesyłały pomiędzy sobą, aby zapewnić wystarczający wzrost produkcji (tzw. syndrom przemysłu cięźkiego). Poza tymi branżami duza ilość wyrobów hutniczych była produkowana na potrzeby przemysłu obronnego i rozwoju infrastruktury kolejowej. Ważnymi odbiorcami były również przedsiębiorstwa wytwarzające maszyny i urządzenia oraz środki transportu.

Z analizy odbiorców, można wnioskować, że zdecydowana większość wyrobów, była przeznaczana na potrzeby rozwoju przedsiębiorstw, a mniejsza część trafiała na cele konsumpcji indywidualnej.

Nastawienie gospodarki na wielkość produkcji powodowała jednocześnie wysoką pracochłonność, materiałochłonność i energochłonność przemysłu. Rezultatem tego było wysokie zatrudnienie względem wartości dodanej, czyli niska wydajność pracy (Ryc. 1).

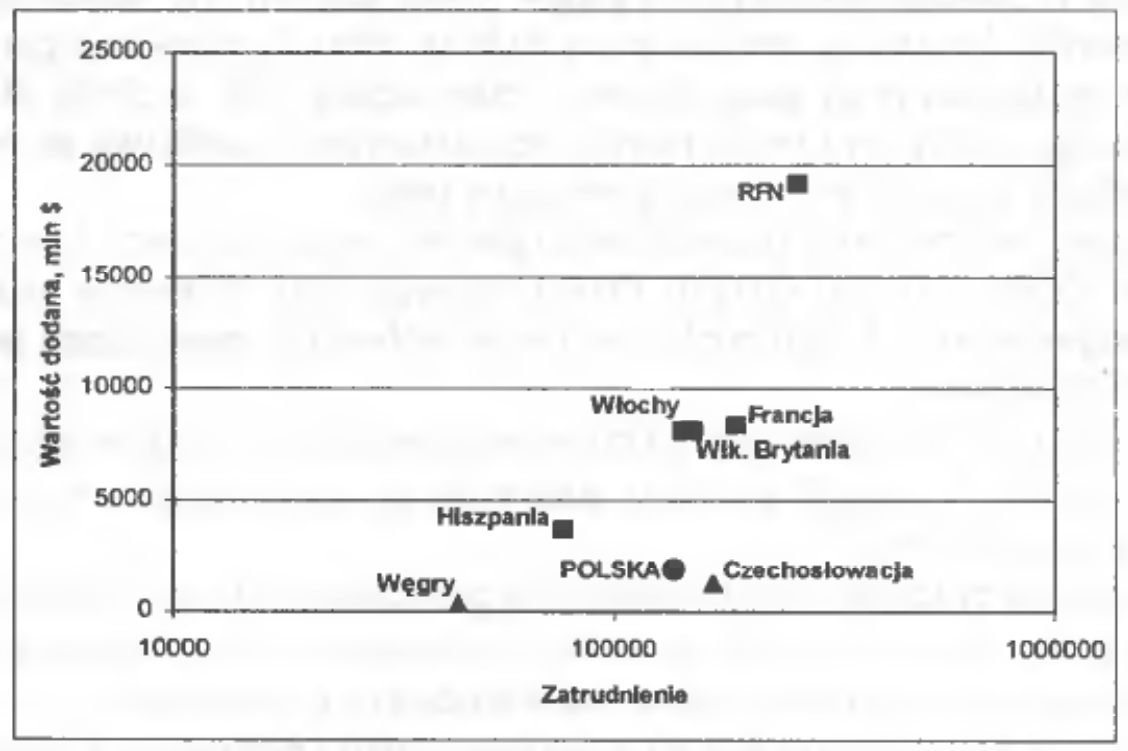

Źródło: Opracowanie własne na podstawie danych UNIDO Industrial Statistics Database Ryc. 1. Wydajnosć pracy w hutnictwie żelaza wybranych krajów w roku 1990

' Wyróżniono następujące rodzaje działalności: 27.1 Produkcja żeliwa i stali oraz stopów żelaza, 27.2 Produkcja rur, 27.3 Obróbka wstępna stali, 28.4 Kucie, prasowanie, wytłaczanie i walcowanie metali; metalurgia proszków. 
Widoczna jest w tym względzie duża różnica w wydajności pracy hutnictwa byłych krajów socjalistycznych i kapitalistycznych. Dążenie do maksymalizacji zysku, będącego podstawą działalności gospodarczej kapitalizmu, powoduje stałe zmniejszanie zatrudnienia w przedsiębiorstwach hutniczych. Możliwe to jest dzięki szybkiemu rozwojowi techniki, umożliwiającemu wdrażanie mniej pracochłonnych technologii. Duży wkład w ten proces ma automatyzacja wielu segmentów procesów produkcyjnych. Nie bez znaczenia były także zmiany z zakresu organizacji pracy. Zatrudnienie w krajach wysokorozwiniętych (Paduch i in. 1997), w okresie głównych przemian restrukturyzacyjnych (lata 1975-1990) zmalało przykładowo:

- Stany Zjednoczone z 500000 do 180000 osób,

- Japonia z 259000 do 162000 osób,

- Wielka Brytania z 200000 do 80000 osób,

- Francja z 160000 do 50000 osób.

Po upadku gospodarki centralnie sterowanej nastapiła konieczność wprowadzenia podobnych mechanizmów ekonomicznych. Technologicznie przestarzałe i mniej efektywne ekonomiczne przedsiębiorstwa, po otwarciu granic straciły część rynków na rzecz importerów. Otwarcie kraju spowodowało więc zmiany w zakresie podaży wyrobów hutniczych w kraju, poprzez pojawienie się konkurencyjnych produktów zagranicznych, co wywołało zmiany w popycie u producentów krajowych.

\section{Przeobrażenia struktur organizacyjnych i wlasnościowych w hutach żelaza GOP-u}

Zmiana warunków gospodarczych w państwie po 1989 roku, wpłynęła na reorganizację przedsiębiorstw. Dotyczyło to zarówno przekształceń wewnętrznych firm jak i zmian w powiązaniach $\mathrm{z}$ podmiotami zewnętrznymi. Wyłączano $\mathrm{z}$ hut wydziały pomocnicze i usługowe takie jak: transport wewnętrzny i zewnętrzny, jednostki remontowe, porządkowe i świadczące usługi socjalne. Uzyskiwały one własną osobowość prawną. Ich dotychczasowa działalność rozszerzała się na inne przedsiębiorstwa, co zapewniało większe możliwości rozwoju. Proces usamodzielniania poprzez tworzenie nowych przedsiębiorstw z czasem objął również wydziały produkcyjne.

Restrukturyzacja organizacyjna przedsiębiorstw sprzyjała również możliwości pozyskania kapitału zewnętrznego. Dla wyodrębnionych zakładów łatwiej było znaleźć inwestora. Najczęściej huty posiadały w tych jednostkach część udziałów bądź akcji, przez co zyski tam generowane mogły być do nich odprowadzane.

Ogrom wydatków związanych z modernizacją technologiczną i dostosowaniem asortymentu produkcji do wymogów rynku, wymagał poniesienia znacznych nakładów kapitałowych. Huty będące wcześniej własnością państwa nie mogły liczyć na wystarczające dotacje ze względu na ograniczony budżet. $Z$ wypracowanych przez siebie środków oraz z zaciągniętych kredytów rozpoczęły przekształcenia. Po pewnym czasie okazało się, że część z przedsiębiorstw nie jest w stanie samodzielnie ukończyć procesu modernizacji i konieczne jest wniesienie kapitału zewnętrznego. Zaistniała potrzeba przynajmniej częściowej prywatyzacji tych przedsiębiorstw.

Proces prywatyzacji przebiegał $\mathrm{w}$ dwóch etapach. W pierwszym dotychczasowe przedsiębiorstwa państwowe uzyskiwały status spółek akcyjnych, których właścicielem był Skarb Państwa - tzw. Jednoosobowe Spółki Skarbu Państwa (JSSP). Utworzona w ten 
sposób spółka wstępuje we wszystkie stosunki prawne, których przedmiotem było przedsiębiorstwo państwowe ${ }^{2}$. Obecnie wszystkie huty Górnośląskiego Okręgu Przemysłowego uzyskały status spółek prawa handlowego, co oznacza, że ten etap związany z ich prywatyzacją mają już za sobą. Proces ten był jednak rozciągnięty w czasie. Pierwszym skomercjalizowanym przedsiębiorstwem była w 1991 roku Huta Katowice, natomiast ostatnimi były huty Baildon i Cedlera w 1999 roku.

Zakończenie tych działań umożliwiło hutom podjęcie poszukiwań inwestorów zewnętrznych, którym według założeń prywatyzacji Skarb Państwa miał udostępnić większościowy pakiet akcji. Niektóre huty zostały sprywatyzowane w wyniku postępowań układowych. Należą do nich: Huta Batory i Huta Jedność. Proces ten polegał na konwersji wierzytelności na akcje przedsiębiorstw. Wierzyciele posiadający łącznie co najmniej $30 \%$ wartości wymagalnych wierzytelności pochodzących z przed 31 grudnia 1996 roku wobec przedsiębiorstwa państwowego lub spółki Skarbu Państwa mogą wnieść o zmianę wierzytelności na akcje $\mathrm{e}^{3}$. Konwersja jest więc znacznie uproszczoną procedurą prywatyzacyjną.

Jedyne istniejące na obszarze GOP-u huty stanowiące do dziś wyłącznie własność Skarbu Państwa to: Huta Katowice, Huta Florian, Huta Cedler, Huta Labędy i Huta Baildon.

Huta Buczek, Ferrum i Pokój zostały włączone do programu Narodowych Funduszy Inwestycyjnych. W 1997 roku Huta Ferrum weszła na warszawską Giełdę Papierów Wartościowych poprzez emisję dwóch serii akcji.

Niektóre z przedsiębiorstw znalazły inwestora strategicznego, przy czym jego pozy skanie odbywało się na różnym poziomie zaawansowania spółki w procesie prywatyzacji. Do najważniejszych inwestorów należą tutaj: Stalexport S.A., K.F.I. Colloseum Sp. z o.o., GEMI Sp. z o.o. W prywatyzowanych hutach pracownicy mieli możliwość objęcia $15 \%$ akcji przedsiębiorstwa.

Spółka Gemi stała się właścicielem Huty Laziska, wykupując jej długi od Górnośląskiego Zakładu Energetycznego. Obecnie posiada 55\% akcji. Gemi od lat zajmowała się importem żelazostopów. Przejęcie udziałów wynikało z dotychczasowej działalności, Huta Łaziska jest bowiem jedynym krajowym przedsiębiorstwem produkującym żelazostopy, będące dla hutnictwa podstawowym surowcem koniecznym do wytopu stali.

Konsorcjum Finansowo - Inwestycyjne „Colloseum” nabyło w 1999 roku ponad $60 \%$ akcji Huty Pokój. Firma ta jest też zainteresowana wykupem pakietu akeji hut Ferrum i Buczek. Jej celem jest zgrupowanie wokół „Colloseum” przedsiębiorstw, które uczestniczyłyby $w$ procesie prywatyzacji i modernizacji energetyki. Dotychczasowe inwestycje zmierzają do utworzenia silnej grupy kapitałowej, w oparciu o możliwości produkcyjne $i$ asortymentowe polskich hut ${ }^{4}$.

Stalexport jako centrala handlu stalą od początku działalności współpracowała z polskimi hutami. W wyniku postępowania ugodowego stała się akcjonariuszem w hutach Jedność i Batory. Do niedawna Stalexport posiadał większości udziałów w Hucie Gliwice. Jest inwestorem strategicznym w spółce Elstal-Labędy będącą największą stalownią elektryczną

\footnotetext{
${ }^{2}$ Podstawa prawna: Ustawa z dnia 30 sierpnia 1996 roku o komercjalizacji i prywatyzacji przedsiębiorstw państwowych.

${ }^{3}$ Podstawa prawna: Ustawa z dnia 3 lutego 1993 roku o restrukturyzacji finansowej przedsiębiorstw i banków oraz zmianie niektórych ustaw.

${ }^{4}$ Problemy związane z zamieszaniem wokół Zarządu Colloseum, stawiają pod znakiem zapytania dalszą działalność konsorcjum na polskim rynku stali.
} 
w GOP-ie. Posiada również pakiety większościowe w kilku hutach poza GOP-em. Ponadto jest poręczycielem wielu zaciągniętych przez huty kredytów.

W wyniku postępowań układowych część akcji hut objęły także inne przedsiębiorstwa takie jak: Polskie Górnictwo Nafty i Gazu, Bank Śląski i inne centrale handlu stalą oraz same huty w tym głównie Huta Katowice. Są to kredytodawcy lub dostawcy materiałów wsadowych, u których huty nie są w stanie wywiązać się ze zobowiązań finansowych.

Poza prywatyzacją całych przedsiębiorstw huty poszukują inwestorów zewnętrznych do wybranych wydziałów, które są następnie wyodrębniane w niezależne podmioty prawne. W ten sposób powstała m.in. spółka Ferropol w 1991 roku. W ostatnim okresie czasu w proces ten włączanych jest coraz więcej zakładów, gdyż w ten sposób łatwiej pozyskać inwestora. Niektóre huty w powiązaniu z zewnętrznym inwestorem zakładają nowe przedsiębiorstwa nie bazujące na dawnych zakładach produkcyjnych. Należą do nich takie firmy jak np.: Elstal-Łabędy (kapitał Huty Łabędy i Stalexportu), Florprofile - Huta Florian i kapitał austriacki. Do wciąż niedokończonych inwestycji tego typu należy budowa Walcowni Rur Jedność (WRJ) przez Hutę Jedność oraz firmy Kulczyk Holding, Stalexport, Bank Śląski i inne. W tym przypadku po dokończeniu tej inwestycji planowana jest likwidacja Huty Jedność i przeniesienie jej produkcji do Walcowni Rur Jedność.

Do zmian organizacyjnych należą także zmiany w sposobie sprzedaży. Gospodarka wolnorynkowa wymusiła rozbudowę komórek zajmujących się zbytem towarów i powstanie działów marketingu, badających zapotrzebowanie rynku oraz wynajdujących nisze popytowe w zakresie produktów stalowych. Część firm utworzyło własne sieci dealerów zajmujących się sprzedażą swoich wyrobów (Ryc. 2).

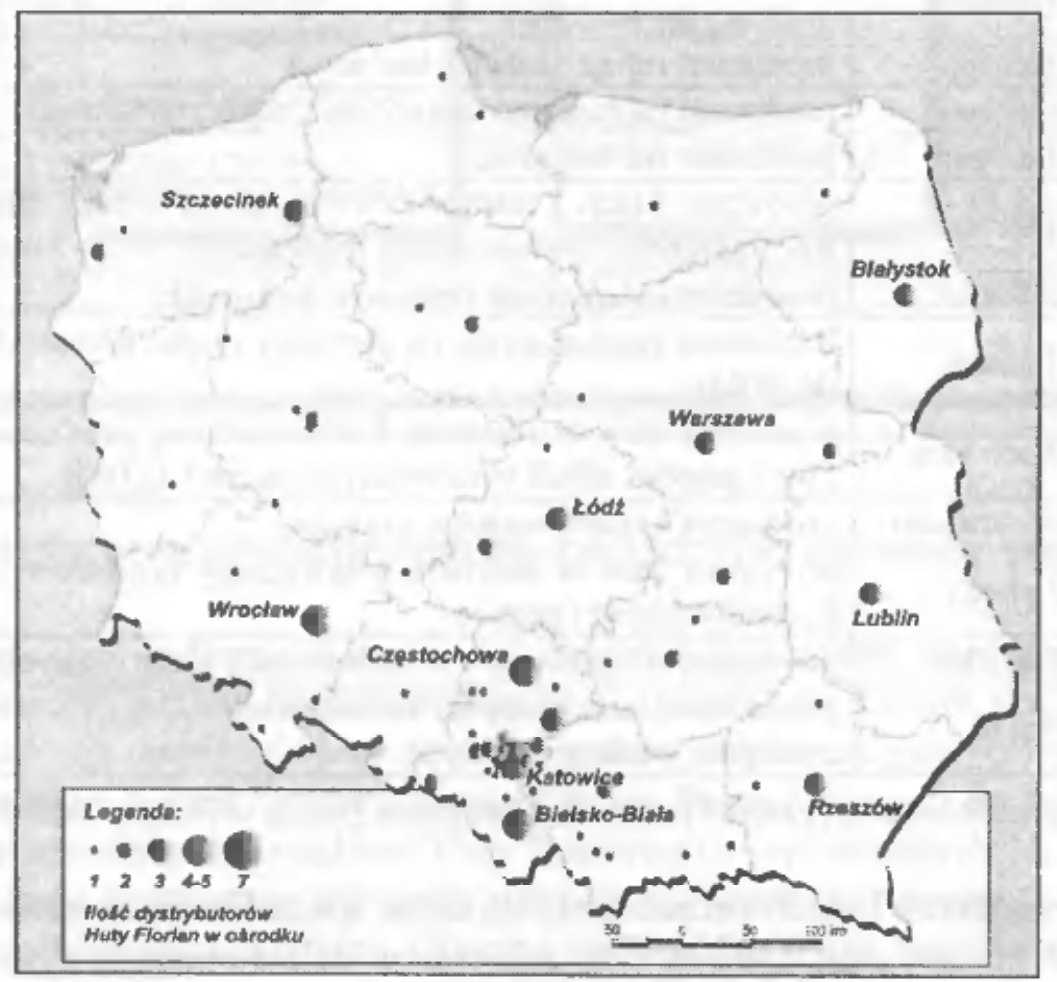

Źródło: Opracowanie własne na podstawie materiałów Huty Florian S.A.

Ryc. 2. Sieć dealerów Huty Florian S.A. (stan na 2 lutego 2001 roku) 
Zasadniczo zmieniło się zapotrzebowanie na wyroby hutnicze. Większosć nowopowstałych przedsiębiorstw przemysłowych w kraju, produkujących w oparciu o nie, musiało importować poszczególne półwyroby. Dotyczyło to przede wszystkim wysoko przetworzonych wyrobów ze stali jakościowej na potrzeby np. branży motoryzacyjnej. Jednocześnie duża część produkcji krajowego hutnictwa nie mogła znaleźć nabywców. Wynikało to ze spadku zamówień u dotychczasowych odbiorców. Odbiciem tej sytuacji był gwałtowny spadek produkcji wyrobów końcowych hutnictwa, co przełożyło się na spadek produkcji stali i surówki w wydziałach surowcowych przedsiębiorstw hutniczych.

Potrzeba utrzymania się na rynku spowodowała konieczność stworzenia spójnej strategii rozwoju polskiego hutnictwa w zakresie struktury asortymentowej produkcji. W oparciu o nią zostały opracowane programy naprawcze przedsiębiorstw. Jednym z ważniejszych ich założeń było określenie segmentu rynku wyrobów stalowych dla poszczególnych hut. Planowaną specjalizację przedsiębiorstw z obszaru Górnośląskiego Okręgu Przemysłowego przedstawiono $\mathrm{w}$ tabeli 1 .

Tabela 1. Założenia docelowej specjalizacji asortymentowej produkcji w hutach GOP-u w oparciu o programy naprawcze hutnictwa w Polsce

\begin{tabular}{|c|c|c|}
\hline Lp. & Przedsiębiorstwo & Profil produkcji \\
\hline 1 & Huta Baildon & $\begin{array}{l}\text { wytwórca stali w stalowni elektrycznej producent blach i taśm } \\
\text { walcowanych na zimno, prętów i walcówki }\end{array}$ \\
\hline 2 & Huta Bankowa & producent kształtowników i prętów \\
\hline 3 & Huta Batory & $\begin{array}{l}\text { wytwórca stali w stalowni elektrycznej producent blach grubych, } \\
\text { prętów i rur bez szwu }\end{array}$ \\
\hline 4 & Huta Buczek & producent rur ze szwem i bez szwu \\
\hline 5 & Huta Cedler & producent taśm walcowanych na zimno i walcówki \\
\hline 6 & Huta Ferrum & producent rur bez szwu \\
\hline 7 & Huta Florian & $\begin{array}{l}\text { producent blach i taśm walcowanych na zimno, blach ocynkowa- } \\
\text { nych ogniowo i powlekanych organicznie, rur ze szwem }\end{array}$ \\
\hline 8 & Huta Gliwice & producent kolejowych zestawów kołowych \\
\hline 9 & Huta Jedność & $\begin{array}{l}\text { Producent rur bez szwu ( } w \text { dalszym etapie przeniesienie produkcji } \\
\text { do WRJ) }\end{array}$ \\
\hline 10 & Huta Katowice & $\begin{array}{l}\text { wytwórca stali w stalowni konwertorowej producent kształtowni- } \\
\text { ków i prętów, blach walcowanych na linii ZOWB }\end{array}$ \\
\hline 11 & Huta Kościuszko & producent ksztaltowników i prętów \\
\hline 12 & Huta Labędy & $\begin{array}{l}\text { wytwórca stali w stalowni elektrycznej producent blach grubych, } \\
\text { kształtowników i prętów }\end{array}$ \\
\hline 13 & Huta Łaziska & producent żelazostopów w stalowniach elektrycznych \\
\hline 14 & Huta Pokój & $\begin{array}{l}\text { producent blach grubych, ksztaltowników, rur ze szwem oraz zela- } \\
\text { zostopów wielkopiecowych }\end{array}$ \\
\hline
\end{tabular}

Źródło: Program Restrukturyzacji Przemysłu Hutnictwa Żelaza w Polsce, IMŹ 1998

W poszczególnych hutach zaznacza się wyraźna specjalizacja asortymentowa produkcji. Największe zmiany dokonano w tym zakresie w dziale surowcowym. Widoczne jest znaczne zmniejszenie ilości stalowni w GOP-ie. W tym też dziale produkcji, poza zamknięciem pozostałych pieców martenowskich, nie przewiduje się większych zmian w ciągu następnych kilku lat. Nastąpią one natomiast na wydziałach wyrobów płaskich 
i dhugich. Istnieje obecnie tendencja do rozbudowy mocy produkcyjnych w zakresie blach natomiast ograniczona ma być produkcja kształtowników. Działania te doprowadzą w przyszłości do zmiany przestrzennej struktury produkcji wydziałów przetwórczych hut GOP-u.

\section{Zmiany technologii wytwarzania wyrobów w hutach żelaza GOP-u}

Nowoczesność linii technologicznych i urządzeń słuzących do wytwarzania wyrobów stalowych ma decydujące znaczenie dla kosztów produkcji, które to z kolei wpływają na możliwości zbytu tych wyrobów na rynku (Ryc. 3).

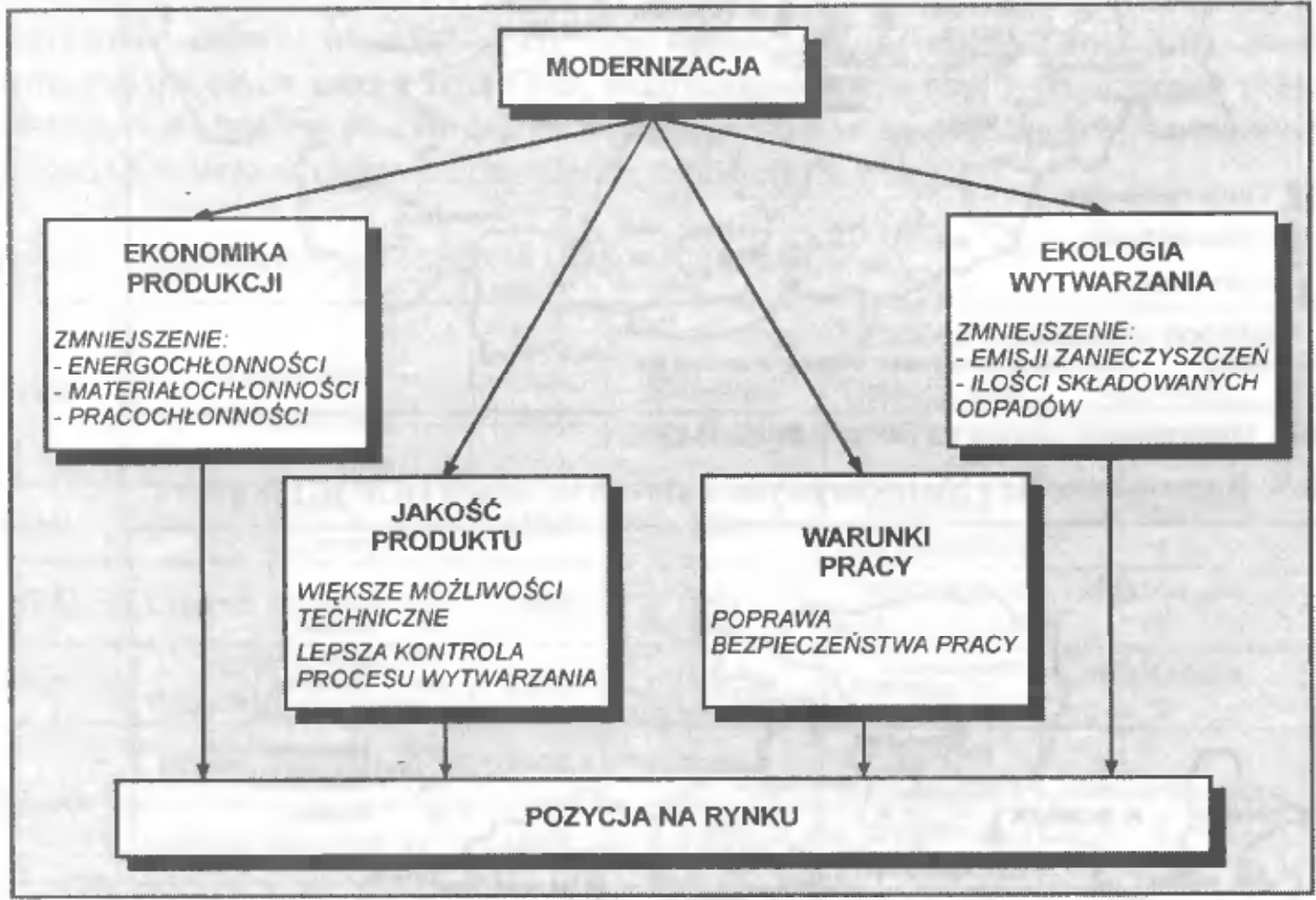

Źródło: Opracowanie własne

Ryc. 3. Schemat wpływu modernizacji technologii produkcji na zajmowaną pozycję na rynku

Rola modernizacji w dostosowaniu do wymogów rynku została zauważona dość wcześnie. Polskie hutnictwo już od lat siedemdziesiątych zaczęło na szerszą skalę wprowadzać w tym zakresie zmiany, mające głównie na celu poprawę jakości otrzymywanego produktu.

Produkcja stali w hutach Górnośląskiego Okręgu Przemysłowego do połowy lat dziewięćdziesiątych pochodziła (z wyjątkiem Huty Katowice) z przestarzałych już wtedy pieców martenowskich. Piece elektryczne stanowiły mniejszość wobec martenowskich a udział wytapianej w nich stali był jeszcze niższy. Obecnie nowoczesne hutnictwo światowe opiera się na wytopie stali wyłącznie w procesie konwertorowym bądź elektrycznym (Ryc. 4 i 5 ). 


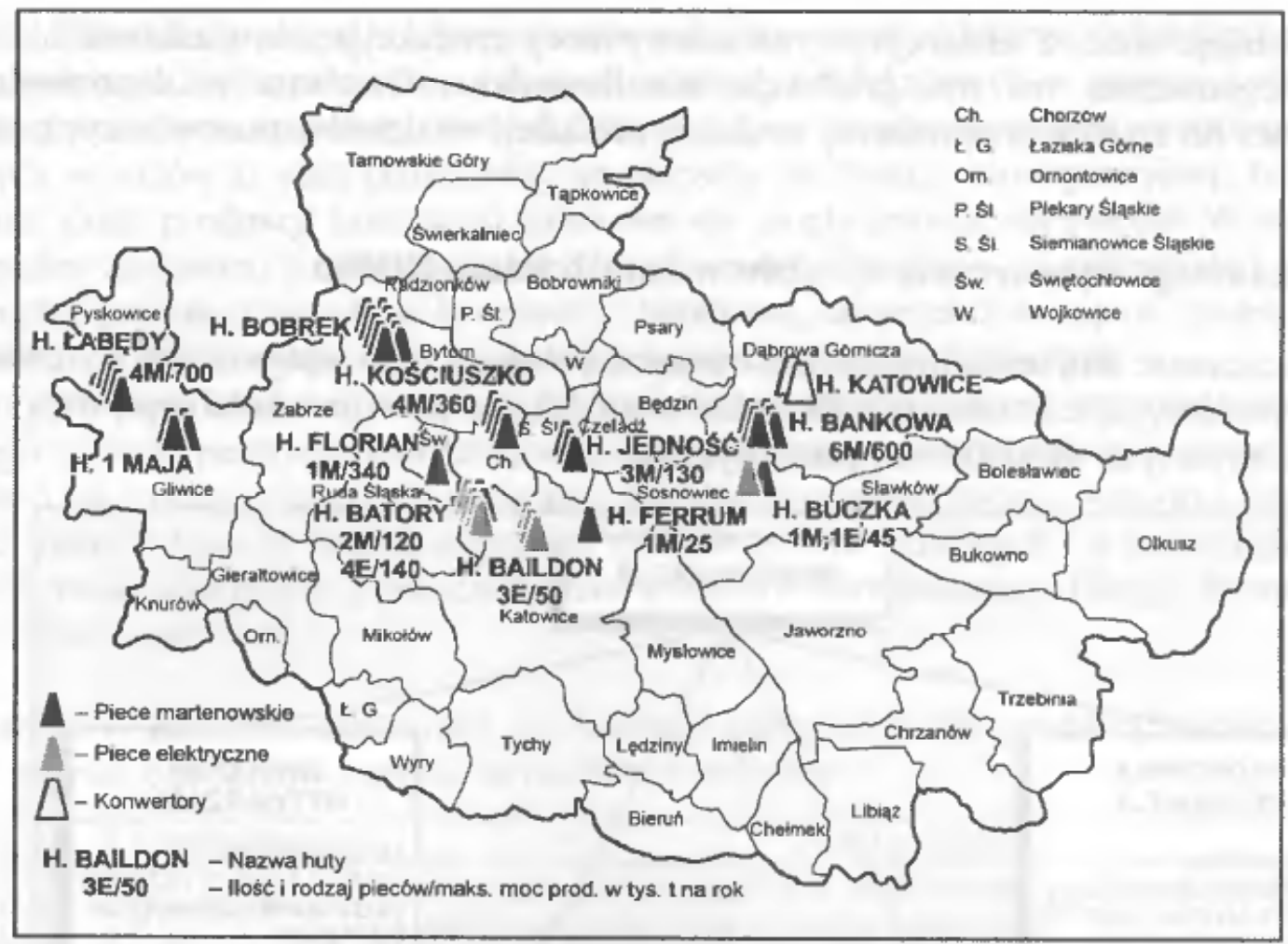

Źródło: Opracowanie własne na podst. danych IMŻ

Ryc. 4. Rozmieszczenie i charakterystyka stalowni w hutach GOP w 1989 roku

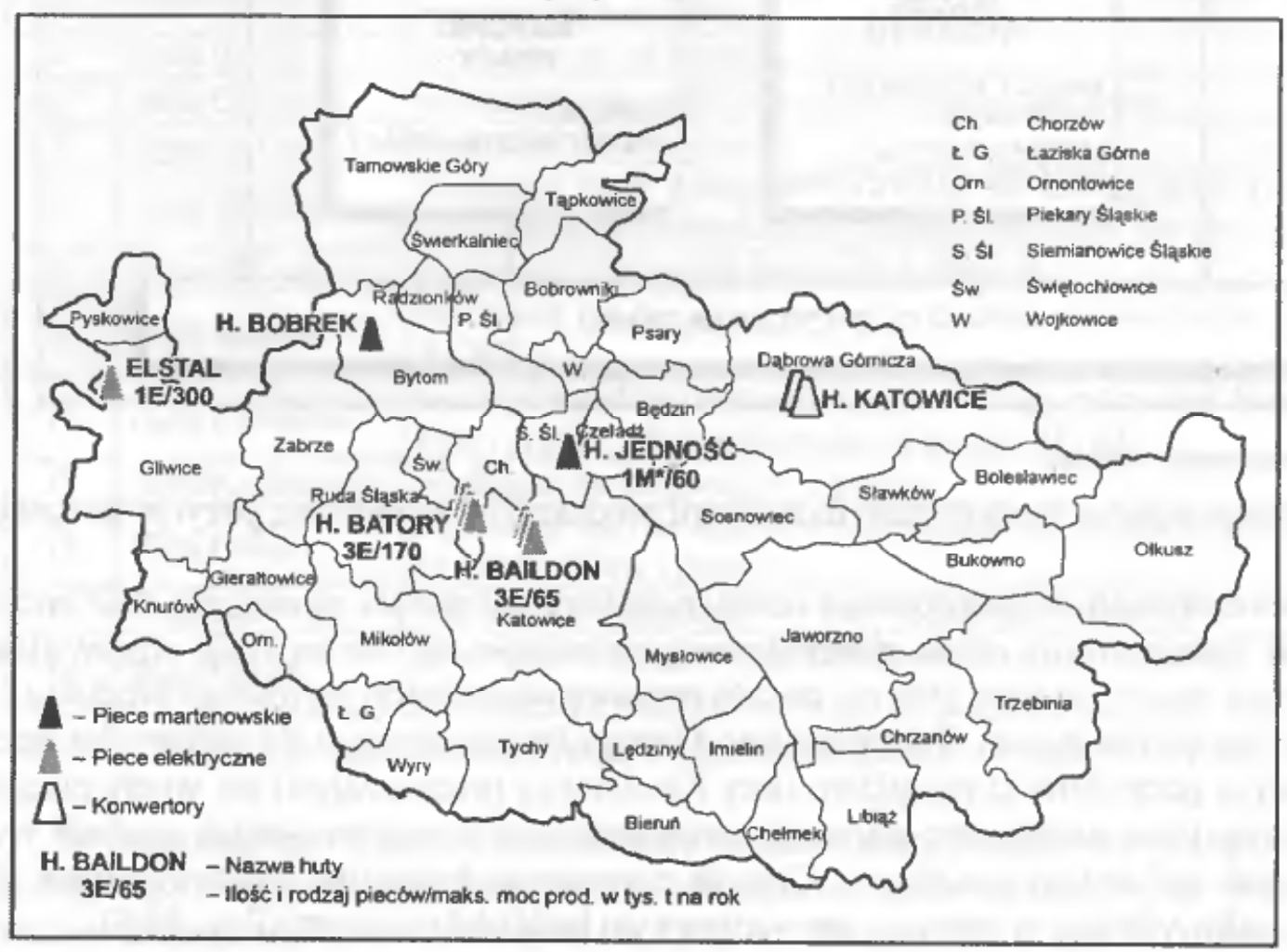

Źródło: Opracowanie własne na podst. danych IMŹ

Ryc. 5. Rozmieszczenie i charakterystyka stalowni w hutach GOP w 1999 roku 
Nasycenie rynku stali i narastająca konkurencja wymuszają wzrost produktywności i redukcję kosztów produkcji w hutnictwie światowym. Objawia się to rozwojem nowoczesnych technologii produkcji oraz rosnącym zintegrowaniem procesów wytwarzania i przetwarzania stali, doprowadzającym do wzrostu uzysku wyrobów gotowych, przy jednoczesnej redukcji kosztów.

Do tych technologii należy ciągłe odlewanie stali - COS Średni uzysk wyrobów gotowych, liczony w stosunku do ciekłej stali w kadzi, poprzez zastosowanie COS-u wzrósł z $76 \%$ do poziomu około $80 \%$ (Grabelus, Bulkowski 1998).

W ciągu ostatnich kilku lat w Polsce nastąpiło znaczne zwiększenie produkcji kęsisk stalowych pochodzących z COS. Przed 1989 rokiem jedyne takie urządzenia na obszarze GOP-u funkcjonowały w Hutach Baildon i Jedność. Likwidacja większości starych i mało efektywnych stalowni martenowskich, przy jednoczesnym uruchomieniu kilku nowych pieców elektrycznych wraz z linią COS, oraz zainstalowanie tego typu urządzeń w Hucie Katowice, wyraźnie zwiększyło udział odlewania stali w sposób ciągły. Charakterystykę urządzeń COS wraz z rokiem uruchomienia zestawiono w tabeli 2.

Tabela 2. Charakterystyka urządzeń COS w hutach GOP-u

\begin{tabular}{|c|c|c|c|c|c|c|}
\hline \multirow[b]{2}{*}{ Huta } & \multirow[b]{2}{*}{$\begin{array}{l}\text { Dostawca } \\
\text { urządzenia }\end{array}$} & \multirow{2}{*}{$\begin{array}{l}\text { Rok } \\
\text { urucho- } \\
\text { mienia }\end{array}$} & \multicolumn{4}{|c|}{ Charakterystyka COS } \\
\hline & & & $\begin{array}{c}\text { Zdolność } \\
\text { produkcyjna }\end{array}$ & $\begin{array}{l}\text { Gatunek stali } \\
\text { odlewu }\end{array}$ & $\begin{array}{l}\text { Stalownia, } \\
\text { ilosć pieców }\end{array}$ & $\begin{array}{c}\text { Ilość } \\
\text { żył }\end{array}$ \\
\hline Jedność & $\begin{array}{l}\text { Biprohut, } \\
\text { polskie huty }\end{array}$ & 1962 & 100 & $\begin{array}{c}\text { węglowe, } \\
\text { niskostopowe }\end{array}$ & $\begin{array}{c}\text { martenowska } \\
1\end{array}$ & 4 \\
\hline ELSTAL & Concast Standard AG & 1995 & 350 & $\begin{array}{c}\text { węglowe, } \\
\text { niskostopowe }\end{array}$ & $\begin{array}{c}\text { elektryczna } \\
1 \\
\end{array}$ & 3 \\
\hline Baildon & $\begin{array}{c}\text { Voest-Alpine- } \\
\text { Industrieanlagenbau }\end{array}$ & 1996 & 60 & stopowe & $\begin{array}{c}\text { elektryczna } \\
2 \\
\end{array}$ & 2 \\
\hline \multirow{2}{*}{ Katowice } & Mannesman Demag & 1995 & 1600 & $\begin{array}{c}\text { węglowe } \\
\text { niskostopowe }\end{array}$ & \multirow{2}{*}{$\begin{array}{c}\text { konwertorowa } \\
2\end{array}$} & 6 \\
\hline & Concast Standard AG & 1998 & 1400 & $\begin{array}{c}\text { węglowe } \\
\text { niskostopowe }\end{array}$ & & 6 \\
\hline
\end{tabular}

Źródło: Grabelus J., Mazur A., Szulc W., 1997, materiały H. Katowice

Główny hamulec modernizacji hutnictwa stanowi niewystarczająca ilość kapitału na tego typu inwestycje, gdyż dla przedsiębiorstw jest to najbardziej kosztowna część programu restrukturyzacji. Możliwe źródła finansowania to: środki własne hut, kredyty bankowe, inwestorzy zewnętrzni, środki budżetowe, śodki pomocowe, emisja obligacji i akcji, Fundusz Ochrony Środowiska. Od pomyślnego zakończenia modernizacji będzie w głównej mierze zależeć przyszłość poszczególnych przedsiębiorstw.

\section{Redukcja zatrudnienia w hutach żelaza GOP-u}

Warunkiem osiagnięcia pełnej efektywności z modernizacji technicznej i technologicznej hutnictwa jest równoległe dokonywanie restrukturyzacji zatrudnienia. 
Problem nadmiernego zatrudnienia w polskim hutnictwie zarysował się już w końcu lat osiemdziesiątych, kiedy to stan zatrudnienia dochodził do 150 tys. osób, podczas gdy zapotrzebowanie rynku zbytu na wyroby hutnicze nie uzasadniało takiego potencjału zatrudnienia. Tak duża liczba osób zatrudnionych w hutnictwie była spowodowana także istniejącą strukturą organizacyjną przedsiębiorstw, które do hutników zaliczały pracowników stołówek, jednostek transportowych, itp.

Konsekwencją restrukturyzacji był duży spadek zatrudnienia $\mathrm{w}$ hutnictwie żelaza i stali w latach 1989-2000 (Ryc. 6). W tym okresie możemy wyróżnić cztery główne etapy redukcji liczby etatów. W pierwszym okresie - do 1992 roku zatrudnienie gwałtownie maleje $\mathrm{i}$ jego spadek wynosi w ciągu trzech lat około $25 \%$, co w liczbach bezwzględnych daje blisko 20 tys. osób. Tak duże zwolnienia były możliwe dzięki nowelizacji przepisów $\mathrm{z}$ zakresu prawa pracys.

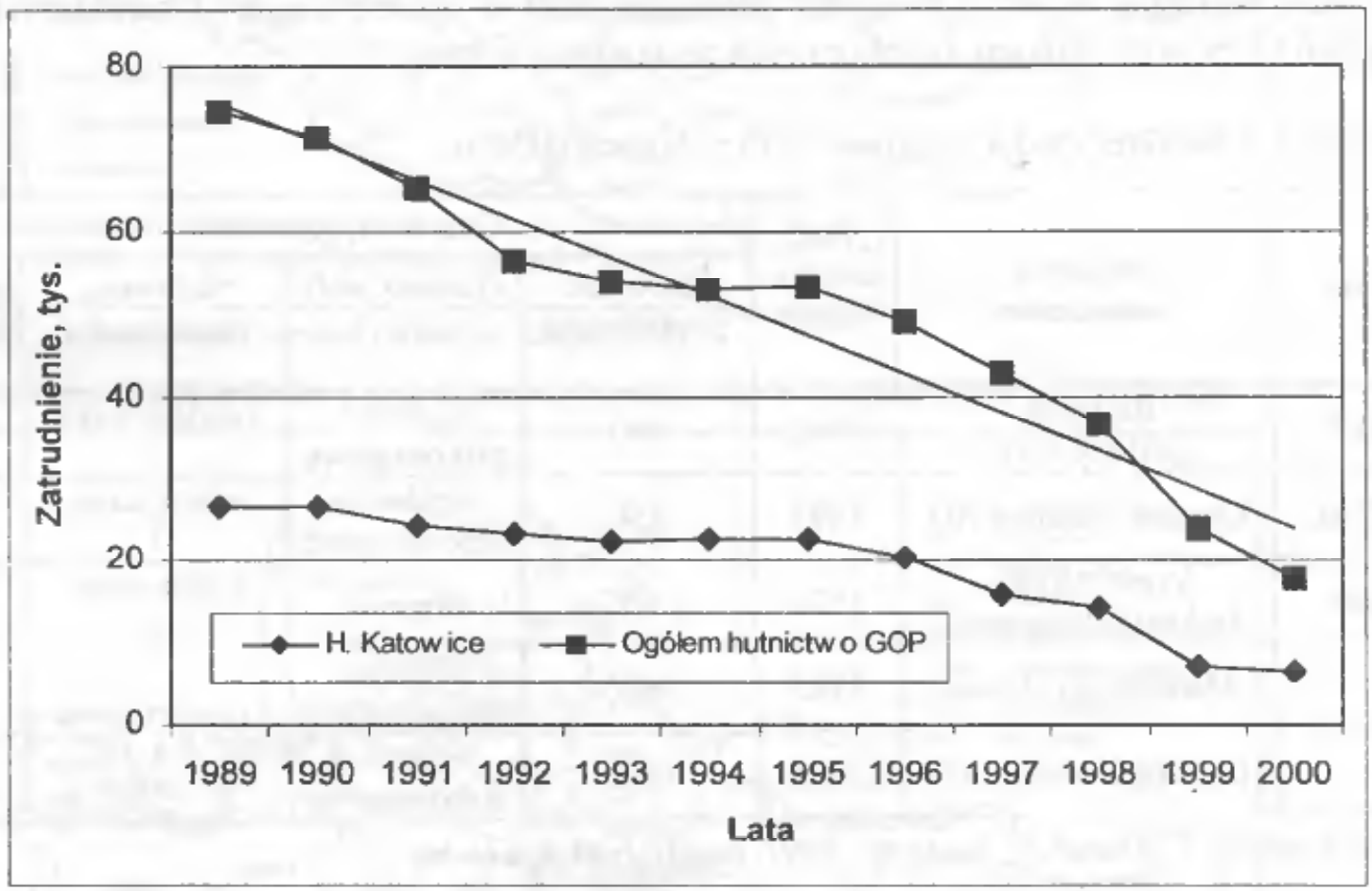

Źródło: Opracowanie własne, na podstawie Paduch j., Barszcz E., materiały przedsiębiorstw Ryc. 6. Zmiana wielkości zatrudnienia w hucie GOP-u w latach 1989-2000

Zmiany powyższych przepisów prawa pozwoliły na wprowadzenie wcześniejszych odejść emerytalnych oraz zwalniania pracowników za odpowiednimi odprawami. Zwolnieniami zostali więc objęci przede wszystkim pracownicy starsi, z długim stażem pracy. Jednocześnie nie był prowadzony nabór nowych pracowników.

Lata 1993-1995 stanowią okres stabilizacji zatrudnienia. Niektóre przedsiębiorstwa w sposób przejściowy nawet nieznacznie zwiększyły zatrudnienie tych latach. Wiązało się

${ }^{5}$ Ustawa z dnia 28 grudnia 1989 roku o szczególnych zasadach rozwiqzywania z pracownikami stosunków pracy z przyczyn dotyczq̨cych zakładu pracy oraz o zmianie niektórych ustaw; Ustawa $z$ dnia 16 października 1991 roku o zatrudnieniu i bezrobociu 
to z wyczerpaniem w znacznym zakresie moźliwości odejść na wcześniejsze świadczenia przedemerytalne, oraz niewielkimi zmianami organizacyjnymi umożliwiającymi odejścia do wydzielonych spółek. Jednocześnie huty unikały stosowania zwolnień grupowych.

Drugie nasilenie redukcji zatrudnienia $w$ hutnictwie przypada na lata 1996-1998. W tym okresie większość hut uzyskało status spółek akcyjnych. Niektóre zmieniły również właściciela, którym do tej pory był skarb państwa, co spowodowało nasilenie się zmian w strukturach przedsiębiorstw. Umożliwiło to redukcje zatrudnienia w hutach poprzez przeniesienie części załogi do wyodrębnianych podmiotów prawnych, powstających w ramach dawnych zakładów. Przesunięcia kadrowe miały największy wpływ na zmniejszenie zatrudnienia w hutach.

Po 1998 roku następuje gwałtowny spadek zatrudnienia. Częściowo jest to wynikiem wprowadzenia kolejnych posunięć prawnych ${ }^{6}$, łagodzących koszty spoleczne zwolnień pracowników. W tym okresie występuje także największa redukcja zatrudnienia w wyniku zmian organizacyjnych.

\section{Dzialania w żakresie ochrony środowiska w hutach żelaza GOP-u}

W Górnośląskim Okręgu Przemysłowym uciążliwość przemysłu, w tym i hutnictwa, jest szczególnie odczuwalna, ze względu na dużą jego koncentrację, która przyczyniła się do znacznej degradacji ekologicznej tego obszaru.

Zanieczyszczenia spowodowane przez hutnictwo żelaza są wynikiem:

- emisji zanieczyszczeń pyłowych i gazowych do atmosfery,

- składowania uciążliwych odpadów na hałdach,

- zrzutu ścieków do wód powierzchniowych.

Głównymi źródłami powstawania powyższych zanieczyszczeń są wydziały surowcowe hut. W ich obrębie natomiast największy wpływ na emisję poszczególnych gazów mają odpowiednio:

- siłownie - $\mathrm{CO}, \mathrm{SO}_{2}$ i $\mathrm{NO}_{x}$,

- spiekalnie - $\mathrm{CO}, \mathrm{SO}_{2}$ i $\mathrm{NO}_{\mathrm{x}}$,

- wielkie piece - $\mathrm{CO}$,

- koksownie - węglowodory.

W latach dziewięćdziesiątych stopień oddziaływania hutnictwa żelaza GOP-u na środowisko naturalne, uległ istotnej zmianie w wyniku likwidacji znacznej części z istniejących tu dotychczas wydziałów produkcji spieku, surówki i stali oraz koksowni.

Obecnie jedyna huta o pełnym profilu produkcji na tym obszarze to Huta Katowice. Proekologiczne urządzenia zainstalowane na jej liniach produkcyjnych spowodowały, że jest ona najlepiej ocenianą pod względem negatywnego wpływu na środowisko, spośród wszystkich polskich hut o pełnym profilu produkcji.

W grudniu 1992 roku Rząd RP przyjął strategię restrukturyzacji polskiego sektora stalowego zawartą w opracowanym przez konsorcjum kanadyjskie „, Studium restrukturyzacji hutnictwa żelaza i stali".

\footnotetext{
${ }^{6} \mathrm{Z}$ początkiem 1999 roku zostało wynegocjowane „Porozumienie $w$ sprawie warunków oston socjalnych procesu restrukturyzacji hutnictwa żelaza i stali-Hutniczy Pakiet Socjalny”
} 


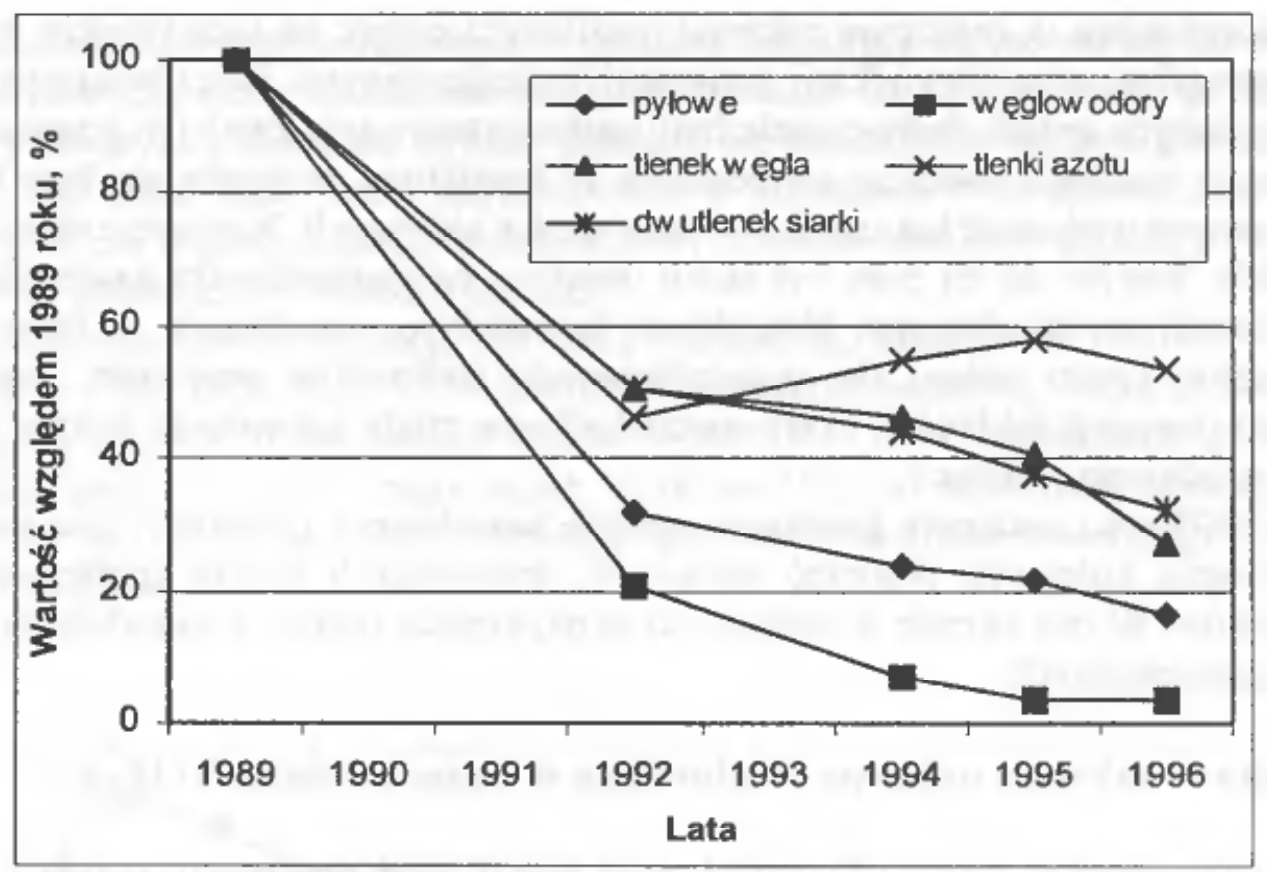

Źródło: Opracowanie własne na podstawie danych IMŻ

Ryc. 7. Poziom emisji zanieczyszczeń powietrza polskiego hutnictwa w latach 1989-1996

Podstawowym założeniem przyjętej strategii było techniczne i organizacyjne zrestrukturyzowanie hutnictwa polskiego, aby wyroby hutnicze produkowane w Polsce osiągnęły międzynarodową konkurencyjność - przynajmniej na rynku polskim, oraz produkcja hutnicza była efektywna ekonomicznie, a jej szkodliwy wpływ na środowisko naturalne jak najmniejszy.

Dla osiągnięcia tych celów konieczne było:

- dostosowanie asortymentu i jakości produkowanych wyrobów do aktualnych wymagań rynku światowego,

- unowocześnienie technologii produkcji,

- dostosowanie potencjału wytwórczego i zatrudnienia do rzeczywistych potrzeb zbywalnej ekonomicznie wielkości produkcji.

$\mathrm{Z}$ pozycji przedsiębiorstwa pierwszym zadaniem $\mathrm{w}$ ramach restrukturyzacji było opracowanie własnej strategii, mieszczącej się w założeniach ogólnego programu rządowego, odpowiadającej na pytania dotyczące:

- segmentów rynku stali, które ma zająć firma,

- asortymentu wytwarzanych wyrobów,

- struktury organizacyjnej przedsiębiorstwa, zapewniającej najlepszą realizację strategii,

- poszukiwania wewnętrznych i zewnętrznych źródeł finansowania restrukturyzacji,

- zmian kadrowych w poszczególnych jednostkach organizacyjnych.

Przebieg realizacji programu oraz częśsiowa weryfikacja jego założeń wykazała potrzebę podjęcia dopuszczalnych prawem i zgodnych $\mathrm{z}$ podpisanymi umowami międzynarodowymi działań wspierających i osłaniających proces zmian strukturalnych w sektorze. Są one niezbędne dla zapewnienia uzyskania ostatecznego celu programu restrukturyzacji, a także dla ochrony osiągniętego stopnia zaawansowania procesu modernizacji technolo- 
gicznej, zmian organizacyjnych, racjonalizacji zatrudnienia oraz zmian własnościowych w sektorze.

Przemiany te do chwili obecnej w większości z hut GOP-u nie zostały dokończone. Niektóre przedsiębiorstwa na dotychczasową restrukturyzację przeznaczyły wszystkie posiadane i możliwe do osiągnięcia środki finansowe. W celu ukończenia procesu modernizacyjnego huty potrzebują doinwestowania ze strony obecnych właścicieli lub nowych inwestorów. Ze względu na wielkość koniecznych nakładów inwestycyjnych, największym problemem będzie dalsza modernizacja Huty Katowice. Aby stała się ona w pełni konkurencyjna, konieczna jest spłata dotychczasowych zobowiązań oraz zainstalowanie linii zintegrowanego odlewania i walcowania blach, będące dokończeniem głównych inwestycji w zakresie przetwórczym huty. Z pozostałych hut w najlepszej sytuacji są te, które dokończyły modernizacje najważniejszych etapów produkcji. Nie muszą one już bowiem ponosić tak wysokich kosztów inwestycyjnych, a z wypracowanego zysku, mogą się dalej rozwijać. Huty znajdujące się w trakcie modernizacji są przeważnie wysoce zadhużone oraz brak im kapitału na dokończenie inwestycji. Przy braku znacznego wsparcia finansowego, ze strony właścicieli będą one skazane na bankructwo.

\section{Literatura}

Grabelus J., Bulkowski L.: 1998, Rozwój ciqgtego odlewania w Polsce w latach 1992-1998, [w:] Prace Instytutu Metalurgii Żelaza, Zeszyt 3, t. 50, Gliwice s. 15-18.

Grabelus J., Mazur A., Szulc W.: 1997, Urzqdzenia ciagteo odlewania stali w hutnictwie polskim, Instytut Metalurgii Żelaza, Gliwice.

Gwiaździński J.: 1972, Hutnictwo żelaza i stali krajów RWPG. PWE, Warszawa.

Paduch J., Barszcz E.: 1998, Restrukturyzacja polskiego hutnictwa żelazana tle zmian na światowym rynku stali, [w:] Prace Instytutu Metalurgii Żelaza, Zeszyt 1, t. 50, Gliwice s. 3-11,

Paduch J., Barszcz E., Wódz J. i in.: 1997, Problemy spoleczne zwiqzane z realizacja programu restrukturyzacji polskiego hutnictwa, [w:] Prace Instytutu Metalurgii Żelaza, Zeszyt 1 t. 49, Gliwice s. 5-10.

Paduch J., Barszcz E.: 1999, Ksztaltowanie nowych jakości oraz racjonalizacja kosztów wytwarzania wyrobów stalowych dostosowanych do wymagań konkurencyjnych rynku, [w:] Prace Instytutu Metalurgii Żelaza, Zeszyt 1 t. 51, Gliwice s. 3-7.

Paduch J., Barszcz E.: 2000, Restrukturyzacja zatrudnienia w krajowym hutnictwie na tle przemian w hutnictwie światowym, [w:] Prace Instytutu Metalurgii Żelaza, Zeszyt 2 t. 52, Gliwice s. 4-11.

Rocznik Statystyczny Przemystu 1970-1987, GUS, Warszawa.

Roczniki Statystyczne województwa katowickiego 1958-1987, WUS, Katowice.

Szulc W., Paduch J., Garbarz B. i in..: 2000, Dostosowanie technologii hutniczych do aplikacyjnych $i$ jakościowych potrzeb rynku, [w:] Prace Instytutu Metalurgii Żelaza, Zeszyt 6, t.52 Gliwice s. 3-33.

Wtaściciele polskich hut, (w:) Nowy Przemysł Nr 4, s. 80-81.

Zdonek B., Mazur A., Szypuła I., Stefaniak A.: 2000, Kierunki optymalizacji kosztów materialów wsadowych, eksploatacyjnych i energii $w$ procesie wytwarzania stali, [w:] Prace Instytutu Metalurgii Żelaza, Zeszyt 2 t. 52, Gliwice s. 30-37. 